\section{A tribute to Burkart Engesser}

\author{
Loïc Costeur · Olivier Maridet · Zhanxiang Qiu • \\ Zhuding Qiu
}

Published online: 13 January 2012

(C) Akademie der Naturwissenschaften Schweiz (SCNAT) 2012

Burkart Engesser is one the most renowned specialists on Cenozoic rodents and insectivores worldwide. His career as palaeontologist started 50 years ago as he entered the Natural History Museum Basel (NMB) in 1962 to work as assistant of Johannes Hürzeler. This period lasted until 1968 when he decided to undertake a PhD thesis under the supervision of Hürzeler who was then head of the Department of Osteology at the NMB and honorary lecturer at the University of Basel. He studied the famous Middle Miocene locality of Anwil located in the vicinity of Basel. Burkart then started to be interested in small animals because the rich locality mainly yielded tiny teeth, which he started to fall in love with. There is indeed an impalpable emotion in bringing tens of millimetre-sized species back to life that are extracted from tons of sediments through the hard and time-consuming collecting-sievingpicking process. He became Doctor in Zoology in 1971 and his seminal work was published in a regional Swiss journal a year later. His talents as scientific illustrator became

L. Costeur ( $\square)$

Naturhistorisches Museum Basel, Augustinergasse 2,

4001 Basel, Switzerland

e-mail: loic.costeur@bs.ch

O. Maridet · Z. Qiu · Z. Qiu

Key Laboratory of Evolutionary Systematics of Vertebrates, Institute of Vertebrate Paleontology and Paleoanthropology, Chinese Academy of Sciences, P.O. Box 643, Beijing 100044, China

e-mail: olivier.maridet@ivpp.ac.cn

Z. Qiu

e-mail: qiuzhanxiang@ivpp.ac.cn

Z. Qiu

e-mail: qiuzhuding@ivpp.ac.cn widely known as he illustrated the hundreds of teeth himself, with incredible accuracy and remarkable aesthetics.

Right after this, he was invited to the United States, at the Carnegie Museum in Pittsburgh as a visiting museum specialist for 9 months. There he further developed his field experience in various regions and met several mammal specialists including the curator for vertebrates, Dr. Mary Dawson, who participates in this volume.

After coming back to Basel, he had the chance to take over the curator position at the NMB after Hürzeler's retirement until his own retirement in 2007. His Museum work includes research, for which he dedicated a large part of his time publishing more than 50 papers in various journals including the most prestigious ones. His contributions cover the fields of systematics, phylogeny, biochronology or palaeoecology mostly of the European continent and the Swiss Alpine foreland basin, but several articles and monographs also deal with faunas of the New World and Asia (see publication list below). But Museum work is also about conservation, in which he involved himself in keeping a high collection standard and in greatly enriching the collection inherited from his famous predecessors Rütimeyer, Stehlin, Schaub and Hürzeler among others. This enlargement is barely visible since tens of thousands of teeth of rodents and insectivores take only a couple of compactor columns in the vast collection, the tons of sediments he brought to Basel being now washed away, probably by the Rhine River! Working in collections also means that you meet colleagues from the whole world, and this is the part Burkart always preferred. Most of the contributing authors of this volume met him in the "Bunker" of the NMB (for those who do not know the expression, it is a typical Swiss bomb shelter to protect scientific goods) and developed projects with him while discussing biochronology or systematics. Besides research and 
collection work, Burkart created parts of the always-to-beseen permanent exhibition of the NMB on recent and fossil mammals. And he did put a lot of himself into the proboscidean part, as an admirer of these giants, probably a reaction to working constantly on a binocular microscope. Burkart also helped along the successful exhibition on Chinese Dinosaurs presented in 1990, and became close friend with several researchers of the Institute of Vertebrate Palaeontology and Palaeonthropology in Beijing, three of whom he already knew having met them at the International Neogene Congress in 1979 in Athens.

One of us (Qiu Zhanxiang), then head of the Neogene Group of the IVPP, was deeply struck by the richness of the European Plio-Pleistocene large mammal fossils in Stehlin's collection when he visited the Naturhistorisches Museum Basel in the framework of the exhibition in 1990. Burkart, being himself a micromammalogist but always extremely kind to palaeontologists specializing in any other animal group, decided to help him to realize his wish to undertake a comparative study of Chinese and European materials. Supported by the Swiss National Fund, Qiu Zhanxiang had the opportunity to spend about 10 months in Basel between 1991 and 1995 to study the European Plio-Pleistocene large mammal fossils, including canids, machairodonts, tapirs, and pigs. These experiences turned out to be of fundamental importance when work started on the Longdan fauna, one of the earliest Quaternary faunas, around 2.2-2.5 Ma, found in Gansu, China. It all ended up with a monograph published in 2004.

From 1994 onwards, Burkart, accompanied by Clemens Mödden, Daniel Oppliger, and Friedrich Heller in separate trips, began to be involved in surveys of the Tertiary continental basins in North-West China. During the field seasons in 1994-2000 and together with their Chinese colleagues, they travelled along the upper reaches of the Huang (Yellow) River, especially in the Lanzhou and Linxia Basins, and the Gansu Hexi Corridor in Gansu. The work in the Lanzhou Basin, conducted by joint teams composed of Swiss, American, and Chinese colleagues, may be considered to be the highlight of the field activities there. More than a hundred fossil sites were found, including some producing micromammal remains screenwashed by Burkart. As a result, five successive reference local faunas were established for the Xianshuihe Formation: the Nanpoping (late Early Oligocene), Xiagou (Late Oligocene), Zhangjiaping (Early Miocene), Duitinggou (Early-Middle Miocene), and Quantougou (Middle Miocene). Despite the publication of preliminary results, it should be noted that the micromammal fossils found from the Lanzhou Basin are so numerous that a large number of them remain undescribed, waiting to be studied.

Also in 1994 Burkart, accompanied by one of us (Qiu Zhuding), visited some fossil localities in eastern and southwestern China, including Shanwang in Shandong province, and Lufeng, Yuanmou and Chenggong in Yunnan province. These Chinese Neogene and Pleistocene localities also attracted his attention because of their abundant or well-preserved mammal remains. Burkart became fascinated with some taxa showing close affinities with European Miocene counterparts, especially those from the hominoid localities of Yunnan, and some relatives of these taxa still living in the tropical or subtropical areas of the Oriental Province. He firmly believes that quite a few of the small mammals living in Yunnan, such as some genera of uropsilines, hylomyines and platacanthomyines, are affiliated with European Miocene forms, and Europe might have had similar ecological conditions during the Miocene as in some current areas of Yunnan.

To investigate these relict forms, he began to explore the forests in Wuliang Mt and Ailao Mt with Daniel Oppliger and his Chinese zoological and palaeontological colleagues in the spring of 2002. He joined Dr. Jiang Xuelong, a zoologist from the Kunming Institute of Zoology, Chinese Academy of Sciences, in the forests to collect specimens and investigate the ecotope of these small mammals during five field seasons until 2007. He paid special attention to some monotypic genera, such as Neotetracus and Typhlomys, which may be closely allied to the Miocene European Lantanotherium and Neocometes, respectively. A manuscript publishing his investigations is ust came out in Vertebrate PalAsiatica (see references). Since the dentition of these hedgehogs have been neither described nor figured in detail so far, their careful character analysis is instructive and will be very useful for palaeontologists and neontologists. Another article on Neotetracus dealing with its external appearance, biotope, behavior in captivity and DNA comparisons with Hylomys, and Neohylomys will be published elsewhere.

The work of Burkart during his career is not only impressive due to the amount of fossil specimens he studied from America, Asia and Europe (Burkart named about 60 taxa all of them being still valid today, see below), but also due to the broad array of disciplines he has been working on. Indeed, besides being a worldwide recognised specialist of rodent and insectivore systematics (two of the most diversified orders of mammals), Burkart also published reference papers about the stratigraphy and biochronology of Europe, especially about the Cenozoic Swiss fresh water molasse and also showed a constant interest in biogeography, palaeoecology and mammalian evolutionary history in his publications. For all this, the contribution of Burkart to the fields of palaeontology and geology is invaluable.

Burkart officially retired in 2007 but keeps on working in Basel and in China; his monograph on the insectivores of the Middle Miocene of Sansan, France, published in the 
Schweizerische Paläontologische Abhandlungen-for which he served as chief editor from 1985 to 2010together with his recent work on hedgehogs are the best evidence of his still active involvement in the field of Palaeontology.

With this special issue dedicated to him, we wish to bring together friends and colleagues who sometimes knew Burkart from the beginning of his career until today. The Swiss Journal of Palaeontology is the successor of the Schweizerische Paläontologische Abhandlungen and we are happy to celebrate Burkart here.

Besides gathering his publication list and the list of the taxa he described along the course of his carrier below, this issue proposes a wide range of disciplines and systematic studies on groups and time periods on which Burkart worked.

To start with, Lorenzo Rook provides an account on the long tradition that linked the Natural History Museum Basel and Tuscany. Indeed, since the second half of the 19th century, Basel palaeontologists were actively working on Tuscan fossils and Burkart followed up the tradition.

Mary Dawson opens the scientific contributions with a biogeographic study of a Palaeogene pantodont genus, which she notes herself was never something that entered the array of Burkart's expertise but when one knows his sense of humour, he will appreciate seeing such a paper dedicated to him!

A third contribution by Marguerite Hugueney, Pierre Mein, and one of us (Olivier Maridet) proposes a detailed description of Early and Middle Miocene Heterosoricinae, Soricinae and Crocidosoricinae from France, they update the systematics of these groups and show the importance of the very rich French localities of this time period. Then, our Chinese colleagues Ni Xijun and one of us (Qiu Zhuding) describe new remains and species of the peculiar tupaiine tree shrews and dedicate a new species to Burkart. This study improves the knowledge of the evolutionary history of tree shrews that until now has been blurred by a relatively poor fossil record. Hans de Bruijn together with Constantin Doukas, Lars van den Hoek Ostende, and Willem Jan Zachariasse provide new data on a Greek fauna that helps determine the chronological context of the deposits and thus the timing of the immigration of murine rodents on Crete. The next contribution by Meinhof Hellmund and Reinhard Ziegler investigates the first micromammal fauna of the Pliocene of Central Germany; detailed description of the material leads to the identification of 13 species of bats, rodents and other insectivores and permits interpretation of the palaeoenvironmental conditions that prevailed. Jérôme Prieto investigates a rodent genus first described by Burkart Engesser in 1979,
Eomyops; he reviews the evolutionary history of this genus around the Middle-Late Miocene transition. Wang Banyue and one of us (Qiu Zhangxian) then describe new muroid rodents from China and dedicate a species to Burkart. Their contribution tends to confirm the peculiarities of genus Tachyoryctoides and the difficulties in assigning it to a known family. Lagomorphs are usually less abundant than rodents or insectivores but are constantly represented in Neogene fossil faunas; Chiara Angelone and Lorenzo Rook review the Late Neogene Italian lagomorph record; a good part of this material in the collection of the NMB was collected by Burkart and his colleagues during the 1970s, 80s, and 90s. Burkart's career also led him to Spain to investigate the Neogene faunal record and he met researchers there who became good friends; Salvador Moyà-Solà and Meike Köhler are among those, and, together with David Alba and Imma Roig, add a contribution on primates to this issue. Their work studies the calcaneal biomechanics in primates and helps provide interesting insights into the locomotor capabilities of Palaeogene European Euprimates.

The two last papers of this volume are dedicated to reconstructions of palaeoenvironments and investigations of palaeoecological parameters of two important Late Palaeogene and Early Neogene European localities framing the Oligocene-Miocene transition. The first one, Rickenbach, is the reference locality for the Palaeogene European biochronological reference level MP 29 and is situated in Switzerland. Burkart is one of the leaders of the understanding of the Swiss Palaeogene-Neogene biostratigraphy and biochronology and as such worked himself on the small mammals of Rickenbach. Bastien Mennecart, Laureline Scherler, Florent Hiard, Damien Becker and JeanPierre Berger pay a tribute to his long Swiss experience in describing the large mammals of Rickenbach and reconstructing its palaeoenvironment. Lastly two of us (Loïc Costeur and Olivier Maridet) together with Stéphane Peigné and Elmar Heizmann study the palaeoecology and palaeoenvironment of one of the richest mammalian localities of the European Aquitanian, Ulm-Westtangente in Germany.

Other colleagues and friends of Burkart would have liked to join us but professional impediments prevented them to do so. Most of them did, however, participate to this issue by reviewing the present papers. We wish to thank all the authors and reviewers for their contributions to this tribute to Burkart Engesser and hope this issue will stimulate research in the fields of systematics, biostratigraphy, biochronology, palaeobiogeography, palaeoecology, palaeoenvironmental reconstructions, which were and still are of great interest to the work of Burkart. 
List of taxa erected by Burkart Engesser(genera are indicated in bold)

\section{LIPOTYPHLA}

\section{ERINACEIDAE}

Mioechinus tobiensis Engesser, 1980

Schizogalerix Engesser, 1980

Schizogalerix anatolica Engesser, 1980

Schizogalerux pasalarensis Engesser, 1980

\section{TALPIDAE}

Desmanella Engesser, 1972

Desmanella stehlini Engesser, 1972

Desmanella cingulata Engesser, 1980

Desmanella sickenbergi Engesser, 1980

Desmanella amasyae Engesser, 1980

Archaeodesmana bifida (Engesser, 1980)

Asthenoscapter ziegleri Engesser and Storch 2008

Desmanodon Engesser, 1980

Desmanodon minor Engesser, 1980

Desmanodon major Engesser, 1980

\section{DIMYLIDAE}

Dimyloides hecki Engesser and Stoch, 2008

Plesiodimylus johanni Kälin and Engesser, 2001

Plesiodimylus crassidens Engesser, 1980

Pseudocordylodon rigassii Engesser, 1976a

\section{PLESIOSORICIDAE}

Plesiosorex schaffneri Engesser, 1972

Plesiosorex martinii Engesser and Storch 2008

\section{SORICIDAE}

Dinosorex Engesser, 1972

Dinosorex pachygnathus Engesser, 1972

Dinosorex zapfei Engesser 1975a

Dinosorex huerzeleri Engesser 1975a

Dinosorex pusillus Engesser and Storch 2008

Quercysorex Engesser 1975a

\section{RODENTIA}

GLIRIDAE

Anthracoglis Engesser, 1983

Anthracoglis marinoi Engesser, 1983

Paraglirulus Engesser, 1972

Paraglirulus werenfelsi Engesser, 1972

Tyrrhenoglis Engesser 1976a

Tyrrhenoglis majori Engesser 1976a

\section{EOMYIDAE}

Eomyodon Engesser, 1987

Eomyodon volkeri Engesser, 1987

Eomyodon weidmanni Engesser 1990b
Eomyodon mayoi Engesser 1990b

Eomyodon staudachensis Engesser 1990b

Pentabuneomys Engesser 1990b

Eomyops Engesser, 1979

Eomyops oppligeri Engesser 1990b

Eomys huerzeleri Engesser, 1982

Eomys molassicus Engesser, 1987

Eomys ebnatensis Engesser, 1987

Pseudotheridomys bernensis Engesser 1990b

Pseudotheridomys werneri Engesser and Storch 2008

Pseudotheridomys rolfoi Engesser 1990b

Rhodanomys hugueneyae Engesser, 1987

Ligerimys oberlii Engesser 1990b

Keramidomys mohleri Engesser, 1972

Keramidomys anwilensis Engesser, 1972

SCIURIDAE

Petauristodon Engesser, 1979

\section{DIPODIDAE}

Plesiosminthus winistoerferi Engesser, 1987

\section{CRICETIDAE}

Eucricetodon hesperius Engesser, 1985

Heterocricetodon hausi Engesser, 1987

Neocricetodon nestori (Engesser, 1989)

Megacricetodon robustus Kälin and Engesser, 2001

Collimys longidens Kälin and Engesser, 2001

Schizocricetodon Kälin and Engesser, 2001

Schizocricetodon huerzeleri Kälin and Engesser, 2001

MURIDAE

Anthracomys lorenzi Engesser, 1989

Apodemus etruscus Engesser, 1989

Huerzelerimys oreopitheci (Engesser, 1989)

\section{References}

Becker, D., Antoine, P.-O., Engesser, B., Hiard, F., Hostettler, B., Menkveld-Gfeller, U., et al. (2010). Late Aquitanian mammals from Engehalde (Molasse Basin, Canton Bern, Switzerland). Annales de Paléontologie, 96(3), 95-116.

Becker, D., Lapaire, F., Picot, L., Engesser, B., \& Berger, J.-P. (2004). Biostratigraphie et paléoécologie du gisement à vertébrés de La Beuchille (Oligocène, Jura, Suisse). Revue de Paléobiologie, sp. vol., 9, 179-191.

Böhme, M., Engesser, B., Martini, E., \& Storch, G. (2005). Eine oberoligozäne Fauna in den Basis-Tuffen des Wasser-kuppenVulkanismus (Rhön). Geologisches Jahrbuch Hessen, 132, 69-78. 
Bolliger, T., Engesser, B., \& Weidmann, M. (1993). Première découverte de mammifères pliocènes dans le Jura neuchâtelois. Eclogae Geologicae Helvetiae, 86(3), 1031-1068.

Burbank, D. W., Engesser, B., Matter, A., \& Weidmann, M. (1992). Magnetostratigraphic chronology mammalian faunas and stratigraphic evolution of the lower freshwater molasse, Haute Savoie, France. Eclogae Geologicae Helvetiae, 85(2), 399-431.

Charollais, J., Weidmann, M., Berger, J. P., Engesser, B., Hotellier, J. F., Gorin, G., et al. (2007). La Molasse du bassin franco-genevois et son substratum. Archives des Sciences, 60(2-3), 59-173.

Engesser, B. (1972). Die obermiozäne Säugetierfauna von Anwil (Baselland). Tätigkeitsberichte der naturforschenden Gesellschaft Baselland, 28, 37-363.

Engesser, B. (1975a). Revision der europäischen Heterosoricinae (Insectivora, Mammalia). Eclogae geologicae Helvetiae, 68(3), 649-671.

Engesser, B. (1975b). Vorläufige Liste der Insectivoren und Chiropteren aus dem höheren Jungtertiär der Türkei. Geologisches Jahrbuch, 15, 119-120.

Engesser, B. (1976a). Tyrrhenoglis majori, ein neuer fossiler Gliride (Rodentia, Mammalia) aus Sardinien. Eclogae Geologicae Helvetiae, 69(3), 783-793.

Engesser, B. (1976b). Zum Milchgebiss der Dimyliden (Insectivora, Mammalia). Eclogae geologicae Helvetiae, 69(1), 795-808.

Engesser, B. (1979). Relationships of some Insectivores and Rodents from the Miocene of North America and Europe. Bulletin of Carnegie Museum of Natural History, 14, 1-68.

Engesser, B. (1980). Insectivora und Chiroptera (Mammalia) aus dem Neogen der Türkei. Schweizerische Paläontologische Abhandlungen, 102, 47-149.

Engesser, B. (1982). Le plus grand représentant du genre Eomys (Rodentia, Mammalia) de l'Oligocène de l'Europe: Eomys huerzeleri nov. sp. Géobios, 15(2), 261-266.

Engesser, B. (1983). Die jungtertiären Kleinsäuger des Gebietes der Maremma (Toskana, Italien). 1. Teil: Gliridae (Rodentia, Mammalia). Eclogae Geologicae Helvetiae, 76(3), 763-780.

Engesser, B. (1985). Die Gattung Eucricetodon (Mammalia, Rodentia) im Grenzbereich Oligozän/Miozän. Eclogae Geologicae Helvetiae, 78(3), 669-692.

Engesser, B. (1987). New Eomyidae, Dipodidae and Cricetidae (Rodentia, Mammalia) of the lower freshwater molasse of Switzerland and Savoy. Eclogae Geologicae Helvetiae, 80(3), 943-994.

Engesser, B. (1989). The late tertiary small mammals of the Maremma region (Tuscany, Italy). 2nd part 2: Muridae and Cricetidae (Rodentia, Mammalia). Bollettino della Società Paleontologica Italiana, 28(2/3), 227-252.

Engesser, B. (1990a). A preliminary mammal zonation of the upper marine molasse of Switzerland. In E. H. Lindsay, V. Fahlbusch, \& P. Mein (Eds.), European neogene mammal chronology (pp. 177-180). New York: NATO Advanced Study Institut Series. 180, serie A, Life Sciences.

Engesser, B. (1990b). Die Eomyidae (Rodentia, Mammalia) der Molasse der Schweiz und Savoyens. Systematik und Biostratigraphie. Schweizerische Paläontologische Abhandlungen, 112, $1-144$.

Engesser, B. (1999). Family Eomyidae. In G. E. Rössner \& K. Heissig (Eds.), The miocene land mammals of Europe (pp. 319-335). Munchen: Verlag Dr. Friedrich Pfeil.

Engesser, B. (2000). Johannes Hürzeler's research on Oreopithecus and the story of the discovery of «Sandrone». Atti del Museo di Storia Naturale della Maremma, 18, 11-23.

Engesser, B. (2001). Transitgasleitung ermöglicht Einblick in die Fauna vor 10 Millionen Jahren. In M. Schmaedecke, P.G. Jordan (Eds.), Ein Schnitt durch den Jura (pp. 61-63). Archäologie und Museum, 43.
Engesser, B. (2005). Switzerland. In L.W.v.d. Hoek Ostende, C.S. Doukas, \& J.W.F. Reumer (Eds.), The Fossil record of the eurasian neogene insectivores (Erinaceomorpha, Soricomorpha, Mammalia), Part I (pp. 285-295).Leiden: Scripta Geologica Special Issue, 5.

Engesser, B. (2009). The insectivores (Mammalia) from Sansan (Middle Miocene, south-western France). Schweizerische Paläontologische Abhandlungen, 128, 1-96.

Engesser, B. (2011). Odontological and craniological comparisions of the recent hedgehog Neotetracus with Hylomys and Neohylomys. Vertebrata Palasiatica, 49(4), 406-422.

Engesser, B., Ginsburg, L., Weidmann, M., \& Bucher, H. (1993a). Les faunes de mammifères et l'âge de la molasse grise de Lausanne (Aquitanien). Bulletin des laboratoires de Géologie, Minéralogie, Géophysique et du Musée géologique de l'Université de Lausanne, 321, 209-259.

Engesser, B., \& Hugueney, M. (1982). Les mammifères de 1'Oligocène supérieur et du Miocène inférieur des profiles de la Findreuse et du Fornant en Haute-Savoie et de la Paudèze près de Lausanne. Documents du Laboratoire de Géologie de Lyon, N.S., 7, 59-75.

Engesser, B., Matter, A., \& Weidmann, M. (1981). Stratigraphie und Säugetierfaunen des mittleren Miozäns von Vermes (Kt. Jura). Eclogae geologicae Helvetiae, 74(3), 893-952.

Engesser, B., \& Mayo, N. A. (1987). A Biozonation of the Lower Freshwater Molasse (Oligocene and Agenian) of Switzerland and Savoy on the basis of fossil mammals. Münchner Geowissenschaftliche Abhandlungen (A), 10, 67-84.

Engesser, B., Mayo, N. A., \& Weidmann, M. (1984). Nouveaux gisements de mammifères dans la molasse subalpine vaudoise et fribourgeoise. Schweizerische Paläontologische Abhandlungen, $107,1-38$

Engesser, B., \& Mödden, C. (1997). A new version of the Biozonation of the Lower Freshwater Molasse (Oligocene and Agenian) of Switzerland and Savoy on the basis of fossil mammals. In: J.-P. Aguilar, S. Legendre \& J. Michaux (Eds.), Actes du Congrès BiochroM'97 (pp. 475-499). Mémoires et travaux de 1'Institut de Montpellier, École Pratique des Hautes Études, Montpellier, 21.

Engesser, B., Schäfer, P., Schwarz, J., \& Tobien, H. (1993b). Paläontologische Bearbeitung des Grenzbereichs Obere Cerithienschichten/Corbicula-Schichten (=Schichten mit Hydrobia inflata) im Steinbruch Rüssingen mit Bemerkungen zur Oligozän/Miozän-Grenze im Kalktertiär des Mainzer Beckens. Mainzer Geowissenschaftliche Mitteilungen, 22, 247-274.

Engesser, B., \& Storch, G. (1999). Eomyiden (Mammalia, Rodentia) aus dem Oberoligozän von Enspel im Westerwald (Westdeutschland). Eclogae Geologicae Helvetiae, 92, 483-493.

Engesser, B., \& Storch, G. (2008). Latest Oligocene Didelphimorpha, Lipotyphla, Rodentia and Lagomorpha (Mammalia) from Obersleichtersbach, Rhön Mountains, Germany. Courier Forschungs-Institut Senckenberg, 260, 185-251.

Engesser, B., \& Ziegler, R. (1996). Didelphids, Insectivores and Chiropterans from the Later Miocene of France, Central Europe, Greece and Turkey. In R. L. Bernor, V. Fahlbusch, \& H. W. Mittmann (Eds.), The Evolution of Western Eurasian Neogene Mammal Faunas (pp. 157-167). New York: Columbia University Press.

Fejfar, O., Engesser, B., \& Tomida, Y. (1997). New eomyid genus and species of Apeomys Fahlbusch 1968 (Eomyidae, Rodentia, Mammalia) affinity from the Early Miocene (MN zones 3 and 4) of Europe and Japan. In: J.-P. Aguilar, S. Legendre \& J. Michaux (Eds.), Actes du Congrès BiochroM'97 (pp.705-706). Mémoires et travaux de $1^{\prime}$ Institut de Montpellier, École Pratique des Hautes Études, Montpellier, 21.

Hürzeler, J., \& Engesser, B. (1976). Les faunes de mammifères néogènes du bassin de Baccinello (Grosseto, Italie). Compte Rendu de l'Académie des Sciences série D, 283, 333-336. 
Kälin, D., \& Engesser, B. (2001). Die jungmiozäne Säugetierfauna vom Nebelbergweg bei Nunningen (Kanton Solothurn, Schweiz). Schweizerische Paläontologische Abhandlungen, 121, 1-61.

Kälin, D., Weidmann, M., Engesser, B., \& Berger, J.-P. (2001). Paléontologie et âge de la Molasse d'eau douce supérieure (OSM) du Jura neuchâtelois. Schweizerische Paläontologische Abhandlungen, 121, 63-101.

Kempf, O., Bolliger, T., Kälin, D., Engesser, B., \& Matter A. (1997). New magnetostratigraphic calibration of early to middle Miocene mammal biozones of the north Alpine foreland basin. In: J.$\mathrm{P}$ Aguilar, S. Legendre \& J. Michaux (Eds.), Actes du Congrès BiochroM'97 (pp. 547-561). Mémoirs et travaux de l'Institut de Montpellier, École Pratique des Hautes Études, Montpellier, 21.

Mojon, P.-O., Engesser, B., Berger, J.-P., Bucher, H., \& Weidmann, M. (1985). Sur l'âge de la molasse d'eau douce inférieure de Boundry NE. Eclogae Geologicae Helvetiae, 78(3), 631-667.

Qiu, Z., Wang, B., Qiu, Z., Heller, F., Yue, L., Xie, G., et al. (2001). Land mammal geochronology and magnetostratigraphy of midTertiary deposits in the Lanzhou Basin, Gansu Province, China. Eclogae Geologicae Helvetiae, 94, 373-385.

Rook, L., Abbazzi L., \& Engesser B. (1999). An overview on the Italian Miocene land mammal faunas. In J. Agustí, L.Rook \& P. Andrews (Eds.). The evolution of neogene terrestrial ecosystem in Europe Volume 1 (pp. 191-204).Cambridge: Cambridge University Press.
Rook, L., Harrison, T., \& Engesser, B. (1996). The taxonomic status and biochronological implications of new finds of Oreopithecus from Baccinello (Tuscany, Italy). Journal of Human Evolution, 30, 3-27.

Schlunegger, F., Burbank, D. W., Matter, A., Engesser, B., \& Mödden, C. (1996). Magnetostratigraphic calibration of the Oligocene to middle Miocene (30-15 Ma) mammal biozones and depositionnal sequences of the Swiss Molasse Basin. Eclogae Geologicae Helvetiae, 89(2), 753-788.

Sickenberg, O., Becker-Platen, J. D., Benda, L., Berg, D., Engesser, B., Gaziry, W., et al. (1975). Die Gliederung des höheren Jungtertiärs und Altquartärs in der Türkei nach Vertebraten und ihre Bedeutung für die internationale Neogen-Stratigraphie. Geologisches Jahrbuch, B, 15, 1-67.

Storch, G., Engesser, B., \& Wuttke, M. (1996a). Oldest fossil record of gliding in rodents. Nature, 379, 439-441.

Storch, G., Engesser, B., \& Wuttke, M. (1996b). Ältester Fossilnachweis eines Gleitfliegers bei Nagetieren. Naturwissenschaftliche Rundschau, 49(9), 371-372.

Weidmann, M., Berger, J.-P., Engesser, B., Reichenbacher, B., Sauvagnat, J., \& Schäfer, P. (2008). La Molasse de la vallée du Joux (Jura suisse et France). Bulletin de la Société vaudoise des sciences naturelles, 91(1), 69-101.

Weidmann, M., Kälin, D., \& Engesser, B. (2003). Les gisements de mammifères aquitaniens de La Chaux (Jura vaudois, Suisse). Bulletin de la Société vaudoise des sciences naturelles, 88(4), 457-482. 